\title{
Fertility in Austria: Past, Present and the Near Future ${ }^{1}$
}

\author{
Tomas Frejka and Jean-Paul Sardon \\ with the assistance of Alain Confesson
}

\section{Introduction}

In the European context, Austria's population has a tradition of low fertility. Already between the world wars of the $20^{\text {th }}$ century Austria had the lowest fertility in Europe. It recovered unevenly in the 1940s and most notably during the 1950s and early 1960s, but has been declining ever since. Early in the $21^{\text {st }}$ century Austria again had one of the lowest fertility rates among Western countries. Around the turn of the century the rate of natural increase was zero. Contemporary childbearing trends and patterns imply that fertility is likely to remain very low and likely to decline further in the foreseeable future. Unless this trend will be reversed, Austria's population will start to decline in size and its population will age rapidly. Immigration could somewhat mitigate these developments.

Between the world wars, Austria distinguished itself by having the lowest fertility not only in Europe but in the world. Vienna had the lowest fertility among large cities. In 1933-34 Austria had a total period fertility rate (TPFR) of about 1.6 births per woman and a net reproduction rate (NRR) equal to 0.66. Vienna's TPFR was 0.6 and its NRR 0.25 (Kirk 1946). Fertility was not much higher in neighbouring countries. Germany in 1933 had a TPFR of 1.6 and a NRR of 0.70 , Switzerland's rates in 1930 were 2.0 and 0.86, respectively, and Bohemia's 1.95 and 0.74, respectively (Kirk 1946).

To arrive at such low numbers took only a few decades. Austria's fertility transition was comparatively fast. Throughout the $19^{\text {th }}$ century the crude birth rate (CBR) was between 31 and 35 per thousand inhabitants (Gisser 1979). ${ }^{2}$ During the last three decades of that century there was an almost imperceptible fertility decline, but basically the CBR was oscillating between 31 and 34 per thousand inhabitants. Even during the first decade of the $20^{\text {th }}$ century the average CBR was still 29.1 (Statistik Austria 2001). A precipitous decline took place during the following two to three decades. The crude birth rate stood at 12.8 per thousand in 1938.

Austria was a relatively prosperous country for most of the $20^{\text {th }}$ century, although the country suffered disproportionately as a consequence of the economic depres-

1 This paper is part of a project entitled "Contemporary cohort reproductive patterns: Low fertility countries in the second half of the $20^{\text {th }}$ and in the early $21^{\text {st }}$ century" initiated in 1999 . A first report on the project was published in 2001 (Frejka, Calot). A comprehensive publication describing the methodology, and providing the analysis as well as findings and conclusions is scheduled to appear in 2004 (Frejka, Sardon).

2 All CBR data refer as best as possible to the present-day territory. 
sion of the 1930s and the second world war. Austria experienced a remarkable recovery during the second half of the century when its economic growth was above the West European average (Prinz et al. 1998). As a result, Austrians were among the wealthiest people in the world in the year 2000, with a per capita gross national income in purchasing power parity of $\$ 26,310$ (World Bank 2002). Over 60 per cent of its GDP was produced in the service sector and an equal proportion of its workforce was employed in that sector.

Since the 1960s, family policy developed into "an integrated component of Government social policy and of income policy" (United Nations et al. 1994). "The Austrian Government is committed to a family policy which includes provisions for establishing conditions in which people can successfully combine the attainment of their basic living requirements with the desire to have children"(United Nations et al. 1994). Expenditures on social protection in purchasing power standards (PPS) per capita were considerably above the European Union average and 10.3 per cent of the social benefits were spent on children and the family, compared to an average 8.5 per cent (Abramovici 2002).

\section{General fertility levels and trends}

Total period fertility was very low throughout the 1930s and it recovered somewhat during the 1940s. Austria experienced a vigorous baby boom during the 1950s and 1960s. Between 1951 and 1961-64 the TPFR increased from 2.0 to a peak of 2.8 births per woman (Figure 1) ${ }^{3}$. A sharp drop in period fertility followed which lasted until 1977 when the TPFR again reached 1.6 births per woman, the level of fertility of the early 1930s. During the 1980s and 1990s, fertility continued to decline unevenly and moderately. In the years 1998 to 2002 the TPFR was around 1.3 to 1.4 births per woman.

It was the cohorts born in the mid-1930s that had the most children, on average an estimated 2.45 per woman. For about 10 successive birth cohorts, fertility declined sharply. The cohort born in 1944 had 1.95 births per woman. Thereafter completed cohort fertility continued to decline steadily. Completed fertility of cohorts born in the mid-1960s was estimated around 1.6 births per woman (Figure 1) . $^{4}$

3 Unless otherwise specified, all data in this paper are from the data bank of the Observatoire Démographique Européen.

4 Only minor proportions of parameters of cohorts that have not yet completed childbearing were estimated by assuming that age-specific ferility rates at ages beyond those that have already been recorded are equal to the most recent observed ones. To minimise errors, no more than 15 percent of the estimated total fertility rate for the youngest cohort is estimated. The method is described in detail in Frejka and Sardon (2004). As a rule, the estimated proportion of any estimated measure is small so that potential errors are also small. Nevertheless, as with all estimates, these are subject to future revision 


\section{Figure 1}

Total period fertility rate, Austria, 1950-2003, and total cohort fertility rate in Austrian birth cohorts 1929-67

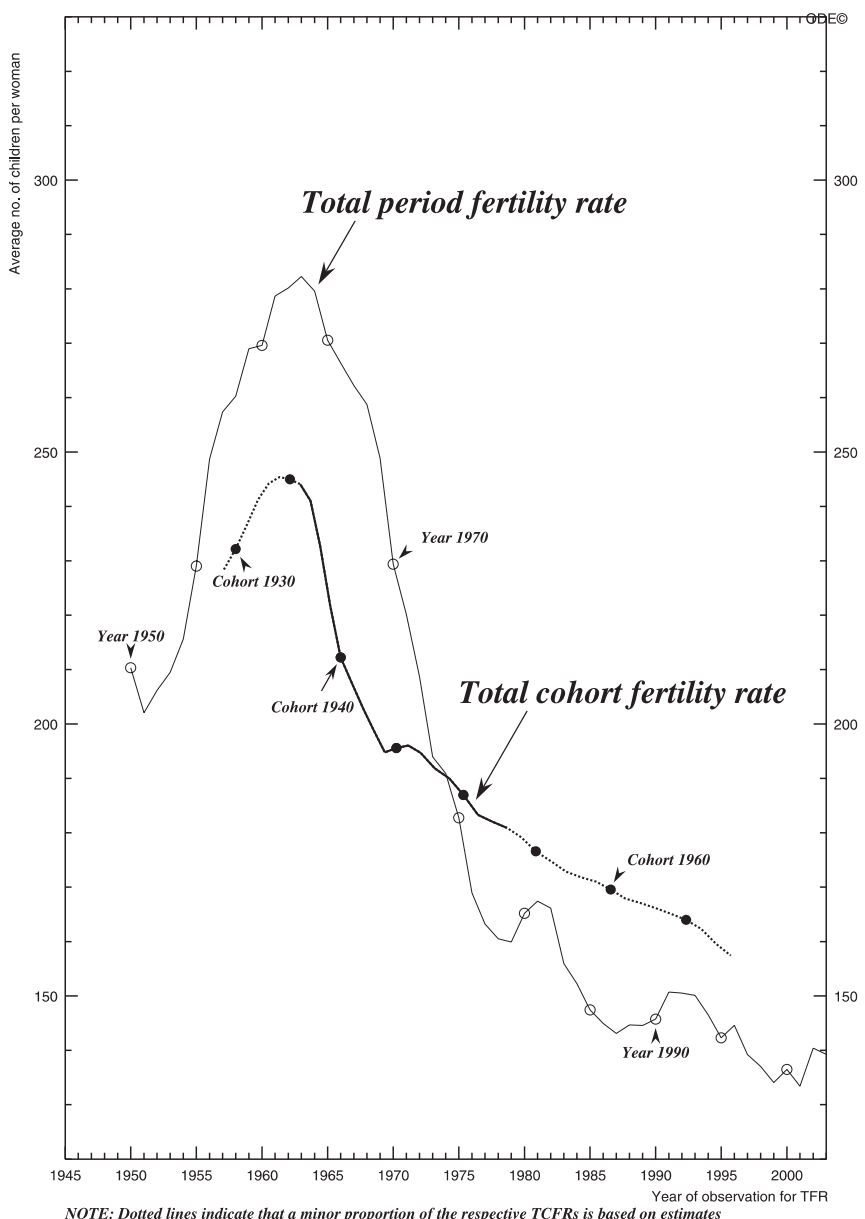

The trends of the total period fertility rates and of the completed cohort fertility rates during the second half of the $20^{\text {th }}$ century were quite similar in Austria and in the neighbouring Western welfare states, West Germany ${ }^{5}$ and Switzerland (Tables 1 and 2 ; Figures 2 and 3). This comes as no surprise as the underlying basic structural social and economic realities evolved along analogous lines. At first, during the 1950s the modern welfare state was established and subsequently strengthened, covering a part of the costs of health and education, providing child benefits and tax relief for those with larger families. It was also a period of unprecedented economic growth with increasing real wages and low unemployment as well as relatively cheap hous-

5 The term "West Germany" applies to the territory of the Federal Republic of Germany as it existed before reunification in 1989. 
Figure 2

Total period fertility rates, Austria and four neighbouring countries, 1950-2003

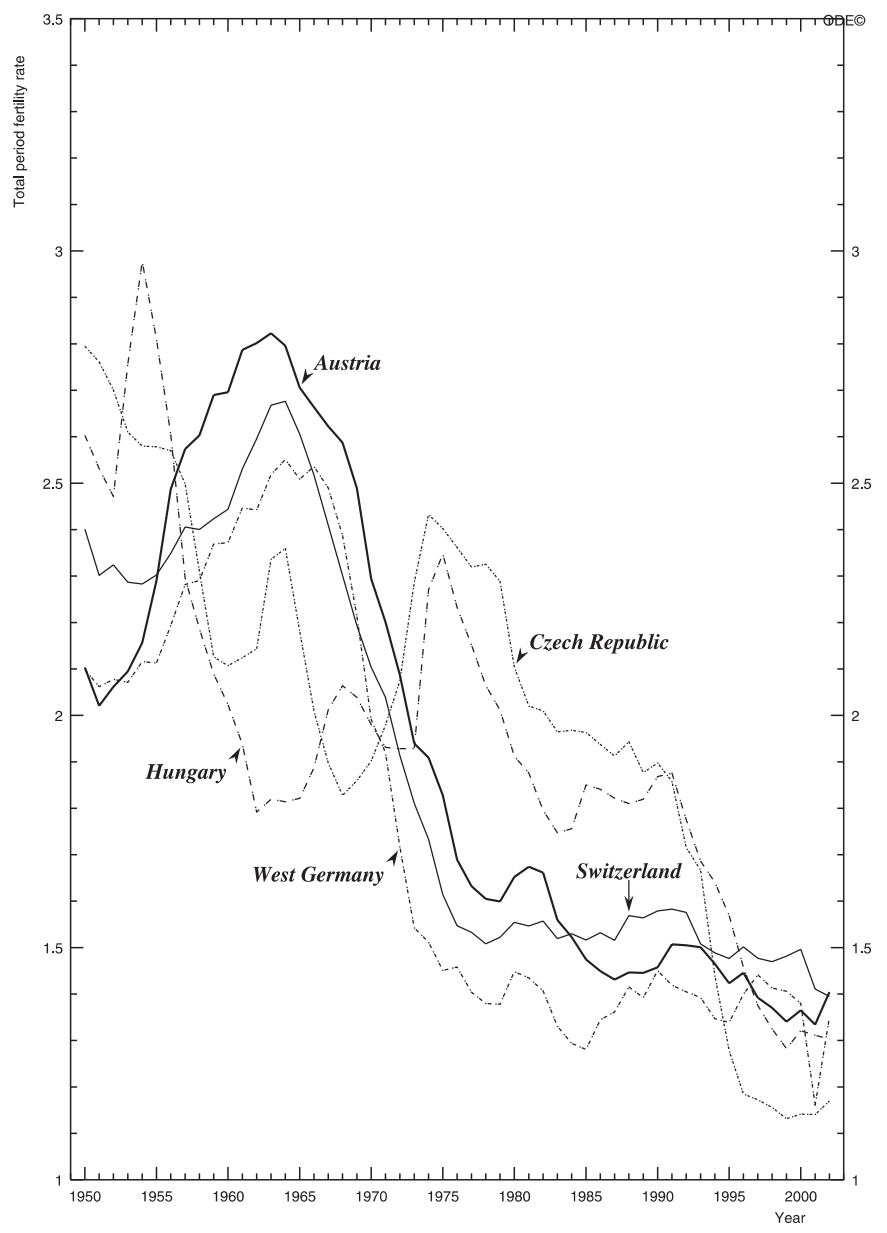

ing available. Gradually conditions for a protracted fertility decline developed. Female labour force participation increased during the 1960s and 1970s. Consequently the time available for household maintenance and childrearing was reduced, and the pressure on the work-family-leisure nexus increased, especially for women. The advent of reliable modern means of contraception and access to safe and legal induced abortion contributed to the realisation of delayed parenthood. Changing patterns of partnership together with increasing divorce rates led to greater uncertainty about the security of the partnerships. Also various aspects of the economic situation changed. Entry into the labour force and subsequent asset accumulation was delayed by extended training. By the 1990s, as a consequence of changing economic and political circumstances, the welfare state was weakened (Hobcraft and Kiernan 1995), although to a lesser degree in Austria compared to other Western European countries. 
Figure 3

Total cohort fertility rates, Austria and four neighbouring countries, birth cohorts 1920-1971

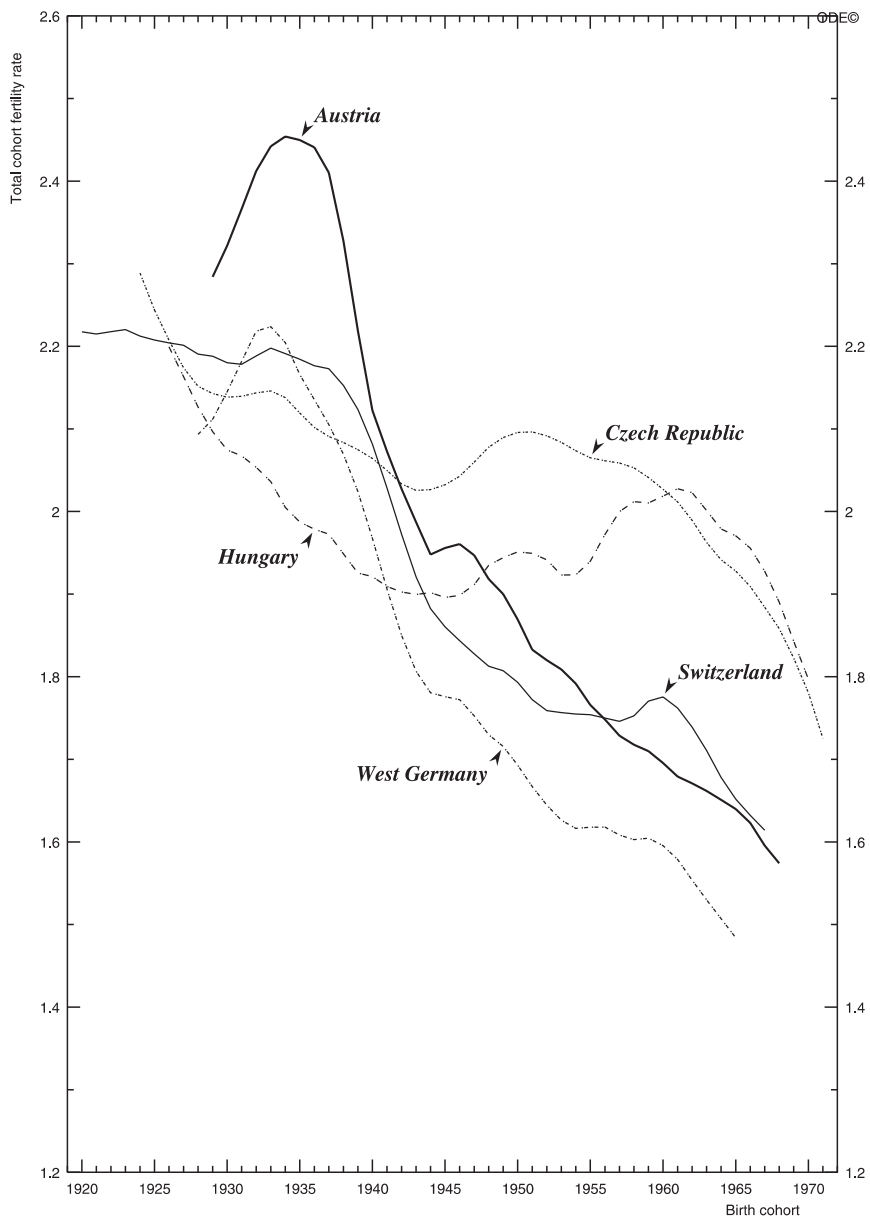

Table 1

Total period fertility rates, Austria and four neighbouring countries, 1950-2002

\begin{tabular}{|l|c|c|c|c|c|c|c|c|c|}
\hline \multirow{2}{*}{ Country } & \multicolumn{4}{|c|}{ Total period fertility rate } & \multicolumn{4}{c|}{ Annual change (per cent) } \\
\cline { 2 - 11 } & $\mathbf{1 9 5 0}$ & $\mathbf{1 9 6 5}$ & $\mathbf{1 9 7 5}$ & $\mathbf{1 9 8 5}$ & $\mathbf{2 0 0 2}$ & $\begin{array}{l}\mathbf{1 9 5 0 -} \\
\mathbf{1 9 6 5}\end{array}$ & $\begin{array}{l}\mathbf{1 9 6 5 -} \\
\mathbf{1 9 7 5}\end{array}$ & $\begin{array}{l}\mathbf{1 9 7 5}- \\
\mathbf{1 9 8 5}\end{array}$ & $\begin{array}{l}\mathbf{1 9 8 5}- \\
\mathbf{2 0 0 2}\end{array}$ \\
\hline Austria & $\mathbf{2 . 1 0}$ & $\mathbf{2 . 7 1}$ & $\mathbf{1 . 8 3}$ & $\mathbf{1 . 4 7}$ & $\mathbf{1 . 4 0}$ & $\mathbf{1 . 7}$ & $\mathbf{- 3 . 9}$ & $\mathbf{- 2 . 2}$ & $\mathbf{- 0 . 3}$ \\
\hline Czech Republic & 2.79 & 2.18 & 2.40 & 1.96 & 1.17 & -1.7 & 1.0 & -2.0 & -3.0 \\
\hline West Germany & 2.10 & 2.51 & 1.45 & 1.28 & $1.38^{1}$ & 1.2 & -5.5 & -1.2 & 0.5 \\
\hline Hungary & 2.60 & 1.82 & 2.35 & 1.85 & 1.30 & -2.4 & 2.5 & -2.4 & -2.1 \\
\hline Switzerland & 2.40 & 2.61 & 1.61 & 1.52 & 1.40 & 0.5 & -4.8 & -0.6 & -0.5 \\
\hline
\end{tabular}


Table 2

Total cohort fertility rates, Austria and four neighbouring countries, birth cohorts 1930, 1940, 1950, 1960 and 1965

\begin{tabular}{|l|c|c|c|c|c|c|c|c|c|}
\hline \multirow{2}{*}{ Country } & \multicolumn{4}{|c|}{ Total fertility rate of cohort born in } & \multicolumn{3}{c|}{$\begin{array}{c}\text { Annual change between birth cohorts } \\
\text { (per cent) }\end{array}$} \\
\cline { 2 - 11 } & $\mathbf{1 9 3 0}$ & $\mathbf{1 9 4 0}$ & $\mathbf{1 9 5 0}$ & $\mathbf{1 9 6 0}$ & $\mathbf{1 9 6 5}^{\mathbf{1}}$ & $\begin{array}{l}\mathbf{1 9 3 0 -} \\
\mathbf{1 9 4 0}\end{array}$ & $\begin{array}{l}\mathbf{1 9 4 0 -} \\
\mathbf{1 9 5 0}\end{array}$ & $\begin{array}{l}\mathbf{1 9 5 0 -} \\
\mathbf{1 9 6 0}\end{array}$ & $\begin{array}{l}\mathbf{1 9 6 0} \\
\mathbf{1 9 6 5}\end{array}$ \\
\hline Austria & $\mathbf{2 . 3 2}$ & $\mathbf{2 . 1 2}$ & $\mathbf{1 . 8 7}$ & $\mathbf{1 . 7 0}$ & $\mathbf{1 . 6 4}$ & $\mathbf{- 0 . 9}$ & $\mathbf{- 1 . 3}$ & $\mathbf{- 1 . 0}$ & $-\mathbf{0 . 7}$ \\
\hline Czech Republic & 2.14 & 2.07 & 2.10 & 2.03 & 1.93 & -0.3 & 0.1 & -0.3 & -1.0 \\
\hline West Germany & 2.14 & 1.97 & 1.69 & 1.60 & 1.48 & -0.9 & -1.5 & -0.6 & -1.5 \\
\hline Hungary & 2.07 & 1.92 & 1.95 & 2.02 & 1.97 & -0.8 & 0.2 & 0.3 & -0.5 \\
\hline Switzerland & 2.18 & 2.08 & 1.79 & 1.78 & 1.65 & -0.5 & -1.5 & -0.1 & -1.4 \\
\hline
\end{tabular}

Note: ${ }^{1}$ Estimates subject to change

Austrian period fertility was higher than in the neighbouring countries during the baby boom as well as during the rapid decline of the 1970s. Once the TPFRs settled around 1.5 and below in the mid-1980s, its fertility was almost identical with the Western neighbours. At the turn of the century, Austria's TPFR stood at 1.3-1.4, practically the same as in West Germany and Switzerland (Table 1 and Figure 2).

Among women born in the 1930s, the TCFR in Austria was considerably higher than in West Germany and Switzerland. Following the precipitous decline among the cohorts of the late 1930s and early 1940s, the TCFRs continued to decline moderately in all three countries. Preliminary estimates of completed fertility of the cohorts that will conclude their childbearing during the first decade of the $21^{\text {st }}$ century are aiming at 1.5 to 1.6 and might even eventually be at or below 1.4 births per woman (Table 2 and Figure 3).

Fertility trends in the neighbouring formerly socialist countries, the Czech Republic and Hungary, were distinctly different from those in Austria throughout the second half of the $20^{\text {th }}$ century. Around the turn of the century, the distinction is fading following the demise of the authoritarian centrally planned political, social and economic systems in these countries (Tables 1 and 2; Figures 2 and 3).

In the Czech Republic and Hungary, fertility was relatively high immediately after the second world war but as the socialist system took hold during the 1950s it declined rapidly to replacement levels. The inefficient national economies became highly labour-intensive and consumer-unfriendly. Female labour force participation increased without adequate services being provided to assist women in their childrearing and household activities. At the same time a number of institutional as well as historical and cultural normative factors were exerting an upward pressure on fertility. Moreover, in the 1950s and early 1960s the socialist governments started to implement a wide range of pro-natalist measures which were subsequently renewed and strengthened, especially in the late 1960s and early 1970s (Frejka 1980). 
The combined effect of these countervailing forces was that the TPFRs in the Czech Republic and Hungary were fluctuating around replacement level until 1990. During the early to mid-1990s TPFRs declined precipitously and then levelled off. In 2002, TPFRs in Hungary and in the Czech Republic were even somewhat lower than in Austria (Table 1 and Figure 2).-Completed fertility rates in these two countries from the cohorts born around 1930 to those of 1960 also fluctuated close to replacement. Subsequently, among the cohorts of the 1960s TCFRs were declining from one cohort to the next and, as will become clear below, this trend will continue (Table 2 and Figure 3).

\section{Age patterns of fertility behaviour}

In comparison to neighbouring Western countries Austrian women were bearing their children early in the reproductive period. In the 1965 birth cohort the mean age of childbearing $(\mathrm{MAC})^{6}$, the most simple albeit inaccurate measure of birth timing, was estimated to be 27.3 in Austria, 28.7 in West Germany and 29.4 years in Switzerland (Figure 4). On the other hand, childbearing on average occurred even earlier in the formerly socialist countries. In the Czech Republic and in Hungary the MAC was estimated as 24.8 and 25.5, respectively, in the 1965 birth cohorts. The differences stand out more starkly when comparing proportions of children born before women's $27^{\text {th }}$ birthday. In the same 1965 cohorts 51 per cent of all births occurred before that birthday in Austria compared to only 34 and 39 per cent in Switzerland and West Germany, respectively. In contrast, in the Czech Republic 74 and in Hungary 66 per cent of all children were born before that birthday (Table 3 ).

Table 3

The proportion of total cohort fertility completed by $27^{\text {th }}$ birthday, Austria and four neighbouring countries, birth cohorts 1930, 1940, 1950, 1960 and 1965

\begin{tabular}{|c|c|c|c|c|c|c|c|c|c|}
\hline \multirow{2}{*}{ Country } & \multicolumn{5}{|c|}{$\begin{array}{l}\text { Proportion of total cohort fertility completed } \\
\text { up to } 27^{\text {th }} \text { birthday of cohort born in }\end{array}$} & \multicolumn{4}{|c|}{$\begin{array}{c}\text { Annual change between birth cohorts } \\
\text { (per cent) }\end{array}$} \\
\hline & 1930 & 1940 & 1950 & 1960 & 1965 & $\begin{array}{l}1930- \\
1940\end{array}$ & $\begin{array}{l}1940- \\
1950\end{array}$ & $\begin{array}{l}1950- \\
1960\end{array}$ & $\begin{array}{l}1960- \\
1965\end{array}$ \\
\hline Austria & $\cdots$ & 62.4 & 66.0 & $\mathbf{5 7 . 0}$ & 51.3 & $\cdots$ & 0.6 & -1.5 & -2.1 \\
\hline Czech Republic & 68.5 & 71.5 & 73.3 & 74.5 & 73.6 & 0.4 & 0.2 & 0.2 & -0.2 \\
\hline West Germany & 46.6 & 61.0 & 58.7 & 45.0 & 38.8 & 2.7 & -0.4 & -2.7 & -3.0 \\
\hline Hungary & 68.8 & 65.9 & 71.7 & 68.2 & 66.3 & -0.4 & 0.8 & -0.5 & -0.6 \\
\hline Switzerland & 40.4 & 56.0 & 51.7 & 38.9 & 33.9 & 3.3 & -0.8 & -2.8 & -2.7 \\
\hline
\end{tabular}

The age pattern of fertility in Austria was changing from one cohort to the next.

6 Changes in the mean age of childbearing reflect changes in the timing as well as parity distribution changes. 
Figure 4

Cohort mean age of childbirth, Austria and four neighbouring countries, birth cohorts 1920-1971

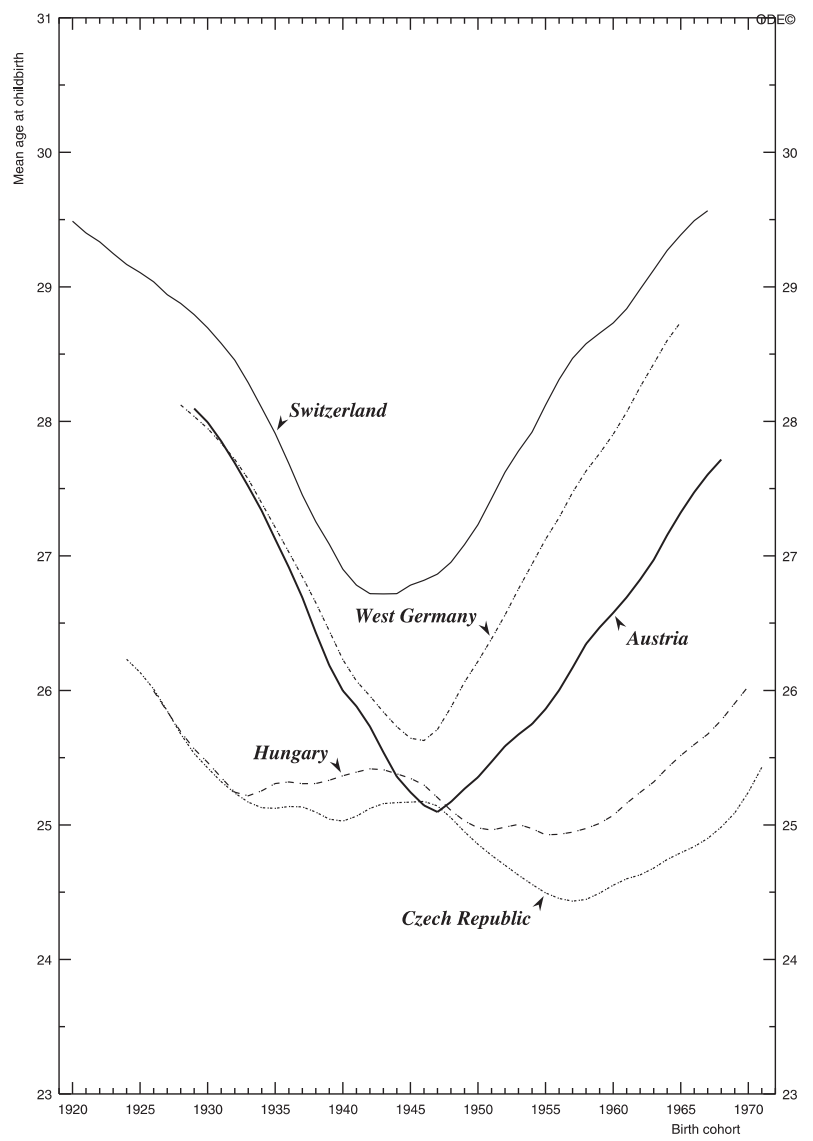

Compared to the 1930 birth cohort, women born in 1940 had significantly advanced their childbearing. The cohort MAC declined from 28.0 to 26.0 years and the age-specific fertility curve of the 1940 birth cohort shifted considerably to the left into younger ages (Figures 4 and 5). Childbearing of young women up to age 26 in the 1940 cohort had increased by 0.25 and when they were older it declined by 0.45 births per woman (Table 4). The advancement of fertility continued among the cohorts born during the first half of the 1940s. In the 1950 cohort, the MAC stood at 25.4 years and the age-specific fertility curve had shifted further to the left (Figures 4 and 5). Compared to the 1940 cohort, fertility in the 1950 cohort was higher among teenagers and women 20 and 21 years old, but much lower among women in their mid-twenties. Age-specific fertility rates between the ages of 24 and 29 were 25 to 30 per cent lower in the 1950 cohort than among women 10 years older.-Note also the considerable shift of the peak in the age-specific fertility curve from age 27 in the 1930 cohort, to age 24 in the birth cohort of 1940, and further to age 21 in the 1950 cohort. 


\section{Figure 5}

Age specific fertility rates, Austria and four neighbouring countries, birth cohorts 1930, 1940, 1950 and 1960.
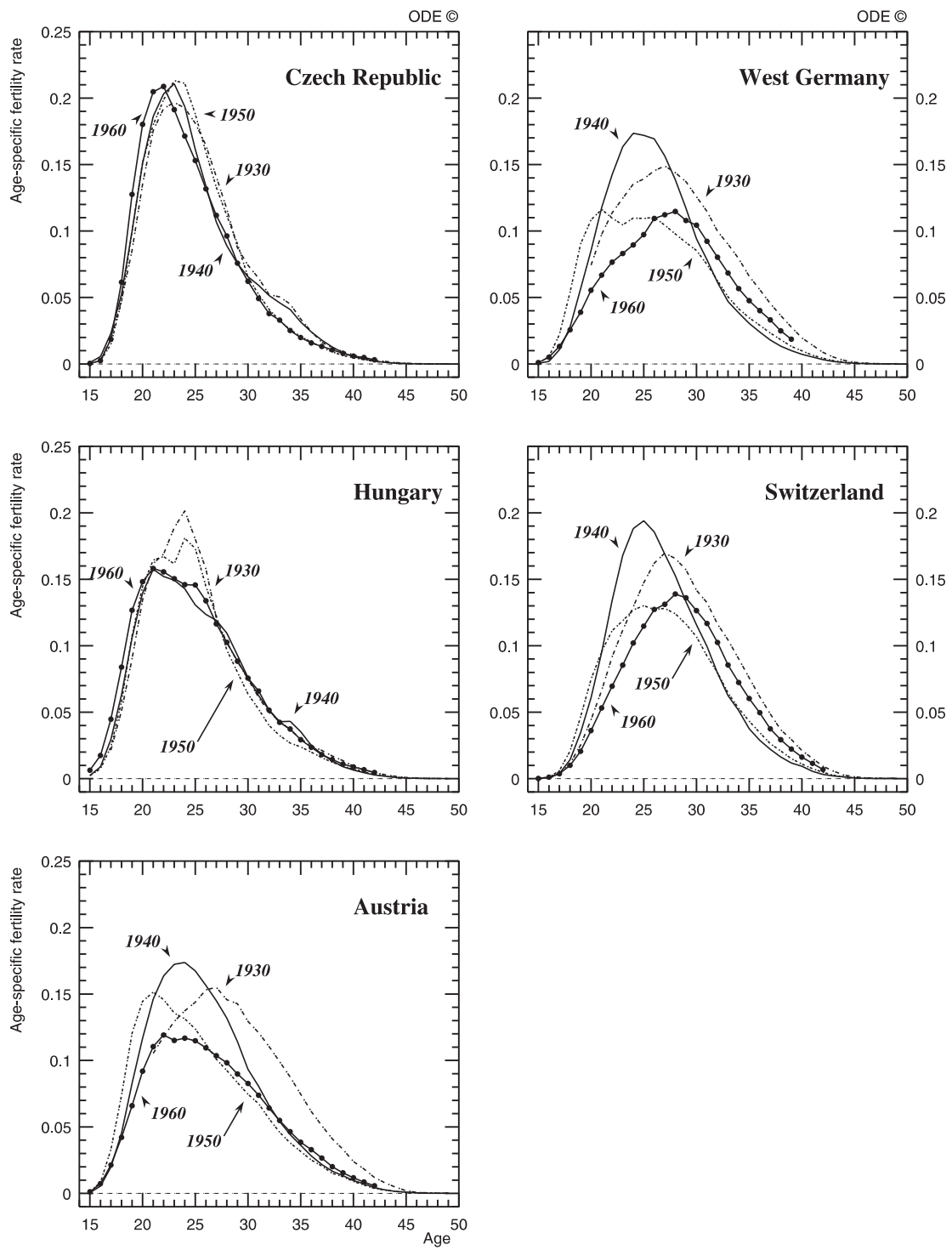

Comparing the 1940 and 1950 birth cohorts in Austria is a simplification which conceals some of the facts. The process of delaying childbearing actually started among the cohorts born during the late 1940s. This cannot be discerned from Table 4 and Figure 5. The lowest MAC, 25.1 years, was recorded in the cohorts born in 1946 and 1947, and from thereon it started to increase (Figure 4). The MAC continued to increase among the cohorts born during the 1950s reaching 26.6 years in the 1960 
cohort and the age-specific fertility curve shifted to the right into older ages (Figures 4 and 5). Childbearing among young women aged 15 to 26 of the 1960 cohort was lower by 0.27 births compared to the 1950 cohort, and slightly higher in the 1960 cohort when these women were 27 and older, namely by 0.09 births per woman (Table 4).

Table 4

Fertility deficits and surpluses comparing birth cohorts, Austria, cohorts 1930, 1940, 1950 and 1960

\begin{tabular}{|l|c|c|c|c|c|c|}
\hline \multirow{2}{*}{ Fertility } & \multicolumn{2}{|c|}{ Cohort 1930 and 1940 } & \multicolumn{2}{c|}{ Cohort 1940 and 1950 } & \multicolumn{2}{c|}{ Cohort 1950 and 1960 } \\
\cline { 2 - 7 } & $\begin{array}{c}\text { Age } \\
\text { group }\end{array}$ & $\begin{array}{c}\text { Number of } \\
\text { children }\end{array}$ & $\begin{array}{c}\text { Age } \\
\text { group }\end{array}$ & $\begin{array}{c}\text { Number of } \\
\text { children }\end{array}$ & $\begin{array}{c}\text { Age } \\
\text { group }\end{array}$ & $\begin{array}{c}\text { Number of } \\
\text { children }\end{array}$ \\
\hline Deficit & $27-49$ & -0.447 & $22-49$ & -0.369 & $15-26$ & -0.266 \\
\hline Surplus & $15-26^{1}$ & +0.251 & $15-21$ & +0.116 & $27-49^{2}$ & +0.092 \\
\hline Total & & $\mathbf{- 0 . 1 9 6}$ & & $\mathbf{- 0 . 2 5 3}$ & & $\mathbf{- 0 . 1 7 4}$ \\
\hline
\end{tabular}

Notes: ${ }^{1}$ Includes estimated data for ages 15-20 in 1930 cohort the total of which was 9.1 per cent of TCFR ${ }^{2}$ Includes estimated data for ages 43-49 in 1960 cohort the total of which was 0.4 per cent of TCFR.

Irrespective of whether childbearing was being advanced or delayed, TCFRs were declining because in all cohorts, from those born around 1930 to those of the early 1960s, fertility deficits at certain ages were always larger than surpluses ${ }^{7}$ (Table 4 and Figure 1). Among the cohorts of the 1930s fertility was declining when women were in their late 20s and older (Figure 5). Among the cohorts of the 1940s, childbearing was declining from one cohort to the next in the prime ages of childbearing. In the 1950s birth cohorts, the fertility decline was among the youngest women. Of the fertility deficit of the young women in the 1960 birth cohort, 0.27 births, only a small proportion was recuperated when they became older, 0.09 births per woman (Table 4). Merely 35 per cent of the births that were "delayed" were actually born when women of the 1960 cohort became older (Table 6).

Another noteworthy consequence of the changes in age patterns of cohort fertility, i.e., the life-time strategies of childbearing, was that they accentuated trends in total period fertility rates (TPFR). The "baby boom" of the late 1950s and early 1960s was not only the result of increased fertility of the women born in the mid-1930s, but to a large extent it was generated by changes in the timing of births. The relatively high "late" childbearing of the mid-1930s birth cohorts, i.e., high

7 Changes in the age structure of cohort fertility can be observed by comparing age-specific fertility rates of one cohort with that of another. In this study usually cohorts born 10 or 5 years apart are compared. When the age-specific fertility rates of a cohort born later (a younger cohort) is higher than that of a cohort born earlier (an older cohort), the difference is considered a surplus. When the age-specific fertility rates of a cohort born later (a younger cohort) is lower than that of a cohort born earlier (an older cohort), the difference is considered a deficit. 
age-specific fertility rates when women were in their late 20 s and early 30 s, overlapped with the "early" childbearing, i.e. relatively high age-specific fertility of women in their late teens and early 20s, of the mid-1940s birth cohorts.- The steep TPFR decline in the late 1960s and the 1970s was in part generated by the delayed births of the cohorts born after the late 1940s. For instance, the relatively low fertility of teenagers and women in their early 20 s in the cohorts born in the early 1960 s overlapped with the equally low fertility of women in their late 20 s in the cohorts born around 1950.

The distribution of fertility by age in birth cohorts of the same years was reasonably similar to Austria in West Germany and in Switzerland (Figure 5). This becomes especially obvious when compared to the age distribution of fertility in the formerly socialist countries where fertility was more compressed around the peak years. Furthermore, changes in the age patterns of fertility between cohorts in Austria were also similar in nature to those in Western countries and different from those in the formerly socialist countries. In the latter, fertility was continuously being advanced into the younger ages, and the age patterns of fertility did not change very much from one cohort to the next. The MAC declined, but the changes were small; from 25.4 years in the 1930 birth cohort to 24.5 in the 1960 cohort in the Czech Republic, and from 25.5 to 25.1 years, respectively, in Hungary. In the Western countries, childbearing was being advanced among the cohorts of the 1930s (Figures 4 and 5), but starting with the cohorts of the 1940s and especially in the 1950s and early 1960s birth cohorts, fertility was being delayed into older ages.

\section{Childbearing of the young generations}

The process of delaying childbearing continued among the cohorts born during the 1960s and 1970s, and the experience of these and previous cohorts during the $20^{\text {th }}$ century indicate that only a proportion of the delayed births were born as women were becoming older (Tables 4, 5 and 6; Figures 6 and 7).

Table 5

Cumulated cohort fertility rates (CCFRs) up to $27^{\text {th }}$ birthday, Austria and four neighbouring countries, birth cohorts 1930, 1940, 1950, 1960, 1970 and 1975

\begin{tabular}{|c|c|c|c|c|c|c|c|c|c|c|c|}
\hline \multirow[t]{2}{*}{ Country } & \multicolumn{6}{|c|}{ CCFRs up to $27^{\text {th }}$ birthday } & \multicolumn{5}{|c|}{$\begin{array}{l}\text { Annual change between birth cohorts } \\
\text { (per cent) }\end{array}$} \\
\hline & 1930 & 1940 & 1950 & 1960 & 1970 & 1975 & $\begin{array}{l}1930- \\
1940\end{array}$ & $\begin{array}{l}1940- \\
1950\end{array}$ & $\begin{array}{l}1950- \\
1960\end{array}$ & $\begin{array}{l}1960- \\
1970\end{array}$ & $\begin{array}{l}1970- \\
1975\end{array}$ \\
\hline Austria & $\ldots$ & 1.326 & 1.234 & 0.967 & 0.732 & 0.631 & $\ldots$ & -0.7 & -2.5 & -3.0 & -3.0 \\
\hline Czech Republic & 1.465 & 1.477 & 1.535 & 1.510 & 1.201 & 0.787 & 0.1 & 0.4 & -0.2 & -2.3 & -8.4 \\
\hline West Germany & 1.001 & 1.200 & 0.994 & 0.718 & 0.524 & $\ldots$ & 1.8 & -1.9 & -3.3 & -3.1 & $\ldots$ \\
\hline Hungary & 1.427 & 1.266 & 1.399 & 1.376 & 1.102 & 0.759 & -1.2 & 1.0 & -0.2 & -2.2 & -7.5 \\
\hline Switzerland & 0.881 & 1.167 & 0.926 & 0.689 & 0.479 & 0.426 & 2.8 & -2.3 & -3.0 & -3.6 & -2.4 \\
\hline
\end{tabular}


Figure 6

Age specific fertility rates, Austria and four neighbouring countries, birth cohorts 1960, 1965, 1970, 1975 and 1980.
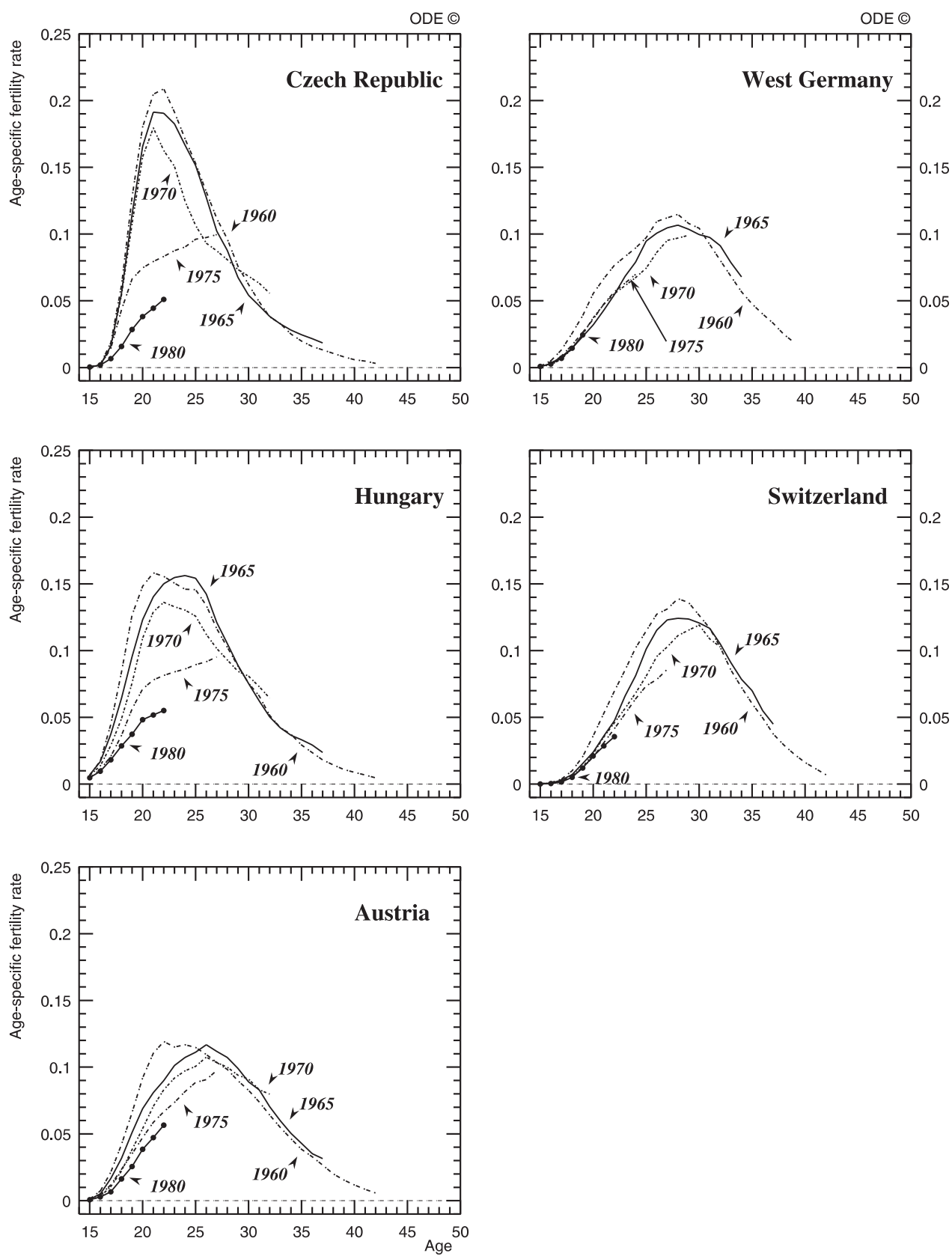
Figure 7

Differences in cumulative age-specific cohort fertility rates between base and subsequent cohorts, Austria and four neighbouring countries, women born in (base) 1955, 1060, 1965, 1970, 1975 and 1980
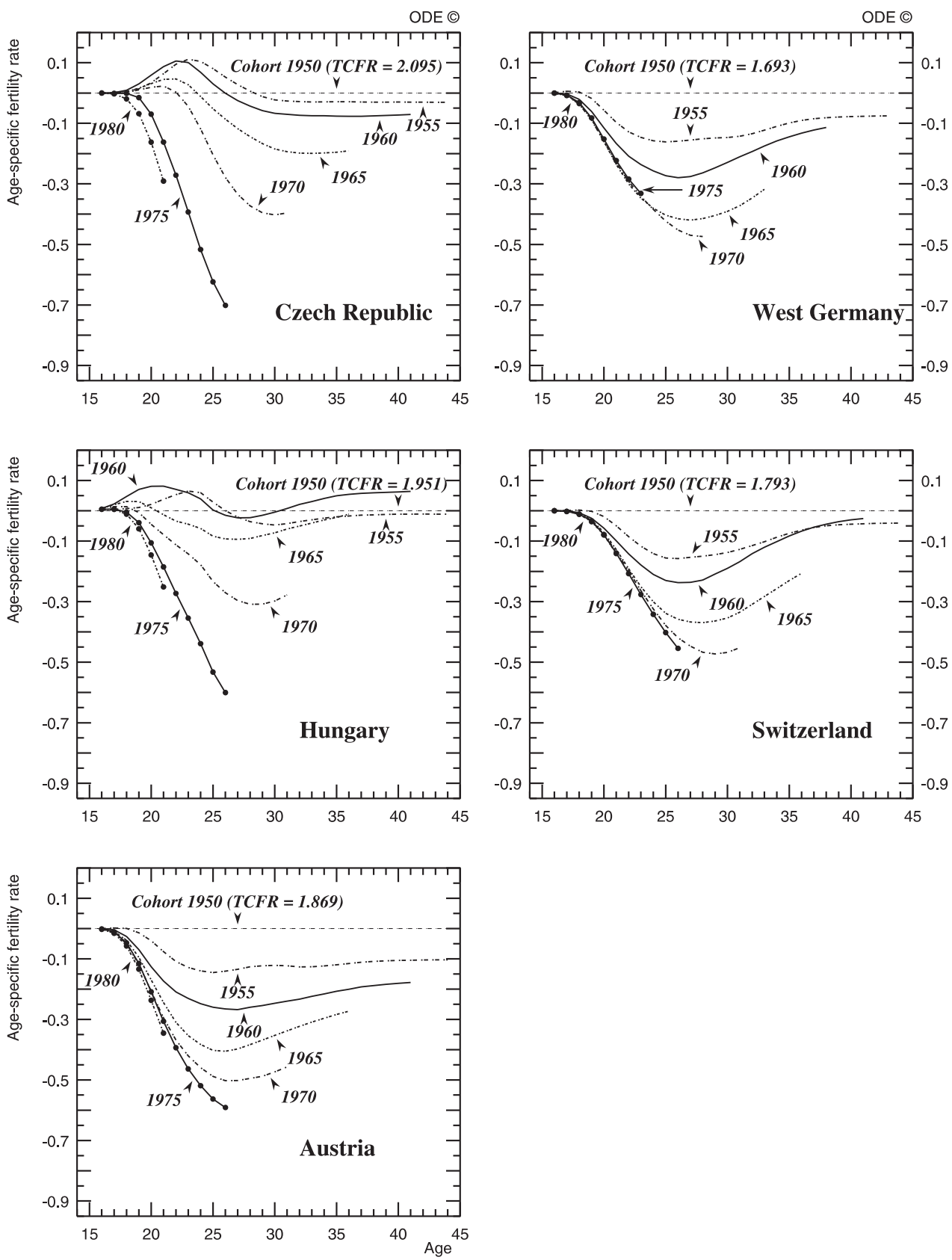
Table 6

Differences in cumulated cohort fertility rates (CCFRs) between successive cohorts and shift ratios, up to and after $27^{\text {th }}$ birthday, Austria and four neighbouring countries, birth cohorts 1930, 1940, 1950, 1960 and 1965

\begin{tabular}{|c|c|c|c|c|c|c|c|c|c|c|c|c|}
\hline \multirow[t]{2}{*}{ Country } & \multicolumn{4}{|c|}{$\begin{array}{l}\text { Differences in CCFRs up to } \\
27^{\text {th }} \text { birthday of successive } \\
\text { cohorts }\end{array}$} & \multicolumn{4}{|c|}{$\begin{array}{l}\text { Differences in CCFRs after } 27^{\text {th }} \\
\text { birthday of successive cohorts }\end{array}$} & \multicolumn{4}{|c|}{$\begin{array}{c}\text { Shift ratios }{ }^{1} \text { (Advancement in } \\
\text { parentheses; Postponement } \\
\text { without parentheses) }\end{array}$} \\
\hline & $\begin{array}{l}1930- \\
1940\end{array}$ & $\begin{array}{l}1940- \\
1950\end{array}$ & $\begin{array}{l}1950- \\
1960\end{array}$ & $\begin{array}{l}1960- \\
1965\end{array}$ & $\begin{array}{l}1930- \\
1940\end{array}$ & $\begin{array}{l}1940- \\
1950\end{array}$ & $\begin{array}{l}1950- \\
1960\end{array}$ & $\begin{array}{l}1960- \\
1965\end{array}$ & $\begin{array}{l}1930- \\
1940\end{array}$ & $\begin{array}{l}1940- \\
1950\end{array}$ & $\begin{array}{l}1950- \\
1960\end{array}$ & $\begin{array}{l}1960- \\
1965\end{array}$ \\
\hline Austria & $\ldots$ & -0.091 & -0.268 & -0.130 & ... & -0.164 & 0.094 & 0.066 & $\ldots$ & $\mathrm{D}^{2}$ & 35 & 51 \\
\hline $\begin{array}{l}\text { Czech } \\
\text { Republic }\end{array}$ & 0.012 & 0.058 & -0.025 & -0.093 & -0.087 & -0.027 & -0.044 & -0.009 & (14) & (216) & D & D \\
\hline $\begin{array}{l}\text { West } \\
\text { Germany }\end{array}$ & 0.198 & -0.206 & -0.276 & -0.144 & -0.380 & -0.068 & 0.177 & 0.030 & (52) & D & 64 & 21 \\
\hline Hungary & -0.161 & 0.134 & -0.023 & -0.071 & 0.007 & -0.104 & 0.090 & 0.021 & 4 & (129) & 388 & 30 \\
\hline Switzerland & 0.286 & -0.241 & -0.237 & -0.131 & -0.385 & -0.048 & 0.218 & 0.006 & (74) & D & 92 & 5 \\
\hline
\end{tabular}

Note: ${ }^{1}$ Ratio of childbearing surplus or deficit of women before and after $27^{\text {th }}$ birthday (in per cent); for instance, in Austria the fertility surplus after the $27^{\text {th }}$ birthday in the 1960 compared to the 1950 cohort was 0.094 , which comprised 35 per cent of the respective deficit, -0.268 , before the $27^{\text {th }}$ birthday

${ }^{2} \mathrm{D}=$ Decline of fertility before and after $27^{\text {th }}$ birthday

The cumulated cohort fertility rate (CCFR) of young women before their $27^{\text {th }}$ birthday was declining continuously starting with the cohorts of the late 1930s. In the 1975 cohort, only 0.6 children were born on average by young women up to age 27 compared to 1.3 children in the 1940 cohort (Table 5). In the cohorts that completed their childbearing, or for which completed fertility can be reliably estimated, none or only a fraction of the delayed births of young women was recuperated when the respective women were older. Comparing the 1950 to the 1940 cohort, fertility declined among women when young as well as when they were older (Table 6). In the 1960 cohort over a third of the delayed births were recuperated when women were in their late 20s or 30s, and it is estimated that among women born in 1965 about half of the delayed births were born when these women were older (Table 6).

Figures 6 and 7 document the continued delay of childbearing in Austria among the cohorts that were in the middle or at the onset of their childbearing years at the turn of the $21^{\text {st }}$ century. Up to their mid-20s, curves of successive cohorts in Figure 6 are lower than those of older ones. After age 25, the curve of the 1965 cohort in Figure 6 is marginally higher than that of the 1960 cohort indicating that some of the delayed births were born; in this case eventually over 50 per cent (Table 6, last col.). In Figure 7 the cumulated fertility rate experience of successive cohorts is depicted in comparison to that of the 1950 cohort, whose TCFR in Austria was equal to 1.9 births per woman. By their mid-20s, the cohorts born in 1970 and 1975 had about 0.5 and 0.6 fewer births than the 1950 cohort, respectively. For each of the cohorts born in 1970 and earlier there is a moderate upswing in their curves when they reach their 
late 20s, however never sufficient to catch up with a previous cohort (Figure 7). By age 30 the cumulated cohort fertility rate of the 1970 cohort was still almost 0.5 births below the 1950 cohort and the propensity to recuperate delayed births appeared weak. It is thus reasonable to venture an educated guess that the completed fertility of this cohort will be in the order of 1.5 births per woman.

The childbearing levels and trends of the cohorts born during the 1960s and 1970s in the neighbouring two Western countries were similar although not identical. Fertility of young women was always higher in Austria (Table 5). In the 1970 birth cohort, for instance, by their $27^{\text {th }}$ birthday Austrian women had given birth to 0.7 children, whereas in West Germany and in Switzerland it was 0.5 children per woman. On the other hand, apparently the propensity to recuperate delayed births when women were older was stronger in Switzerland among the cohorts of the 1950s but not in those of the early 1960s (Table 6 and Figure 7). Consequently TCFRs in that country were marginally higher than in Austria starting with cohorts born in the late 1950s, however the difference virtually disappeared in the cohorts born around 1965 (Table 2 and Figure 3).

The comparison of fertility levels and trends of the cohorts that were in the middle or at the onset of childbearing with the two neighbouring formerly socialist countries is more complex. The childbearing patterns of the cohorts born around 1960 were rather different in these countries compared to Austria; however, there are indications that the childbearing behaviour of the cohorts born during the 1970s started to resemble those of Austria and the other Western countries. - Fertility of young women born during the early 1970s was still higher in the formerly socialist countries even though it started to decline rapidly (Table 5). On average, by their $27^{\text {th }}$ birthday women born in 1975 had given birth to 0.8 children in the Czech Republic and in Hungary compared to 0.6 in Austria. The rate of fertility decline among young women born during the 1970s in the Czech Republic and Hungary was historically unprecedented (Tables 5 and 7; Figures 6 and 7). Even though it is too early to know what the eventual path of the lifetime fertility experience of women born during the late 1970s will look like in Austria's formerly socialist neighbour countries, it is quite obvious that the transition to a new childbearing paradigm was a matter of only very few cohorts, a dramatically rapid change. These were the women who were at the onset of their childbearing careers during the initial years of the major transformations in the political, economic and social systems in the Czech Republic and Hungary during the 1990s. With regard to the comparison with Austria, the childbearing age patterns of the women born in the mid- to late 1970s will apparently be quite similar not only in the neighbouring Western, but also in the neighbouring formerly socialist countries. 
Figure 9

Proportion of childless women, Austria, Czech Republic and Hungary, birth cohorts 1920-1972

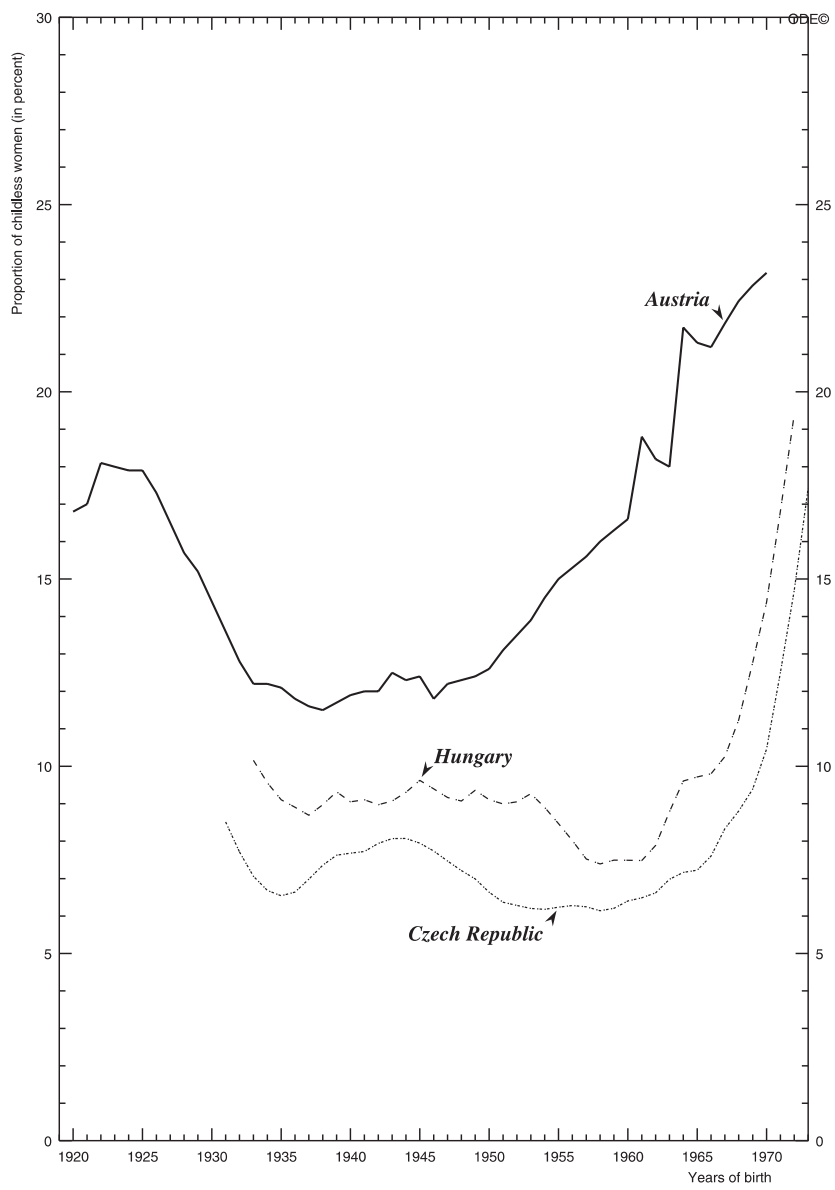

Table 7

Cumulated cohort fertility rates (CCFRs) up to $22^{\text {nd }}$ birthday, Austria and four neighbouring countries, birth cohorts 1930, 1940, 1950, 1960, 1970, 1975 and 1980

\begin{tabular}{|c|c|c|c|c|c|c|c|c|c|c|c|c|c|}
\hline \multirow[t]{2}{*}{ Country } & \multicolumn{7}{|c|}{ CCFRs up to $22^{\text {nd }}$ birthday } & \multicolumn{6}{|c|}{$\begin{array}{c}\text { Annual change between birth cohorts } \\
\text { (per cent) }\end{array}$} \\
\hline & 1930 & 1940 & 1950 & 1960 & 1970 & 1975 & 1980 & $\begin{array}{l}1930- \\
1940\end{array}$ & $\begin{array}{l}1940- \\
1950\end{array}$ & $\begin{array}{l}1950- \\
1960\end{array}$ & $\begin{array}{l}1960- \\
1970\end{array}$ & $\begin{array}{l}1970- \\
1975\end{array}$ & $\begin{array}{l}1975- \\
1980\end{array}$ \\
\hline Austria & $\ldots$ & 0.499 & 0.608 & 0.399 & 0.240 & 0.215 & 0.165 & ... & 2.0 & -4.2 & -5.1 & -2.0 & -5.3 \\
\hline $\begin{array}{l}\text { Czech } \\
\text { Republic }\end{array}$ & 0.559 & 0.620 & 0.596 & 0.701 & 0.599 & 0.324 & 0.162 & 1.0 & -0.4 & 1.6 & -1.6 & -12.3 & -14.0 \\
\hline \begin{tabular}{|l} 
West \\
Germany
\end{tabular} & $\ldots$ & 0.369 & 0.451 & 0.243 & 0.159 & 0.167 & $\ldots$ & $\ldots$ & 2.0 & -6.2 & -4.2 & 1.0 & $\ldots$ \\
\hline Hungary & 0.547 & 0.584 & 0.593 & 0.663 & 0.481 & 0.320 & 0.227 & 0.6 & 0.2 & 1.1 & -3.2 & -8.1 & -6.9 \\
\hline Switzerland & 0.197 & 0.274 & 0.301 & 0.159 & 0.101 & 0.093 & 0.086 & 3.3 & 0.9 & -6.4 & -4.5 & -1.8 & -1.6 \\
\hline
\end{tabular}


Figure 8

Total cohort fertility rates by biological birth order, Austria and two neighbouring countries, birth cohorts 1925-1972
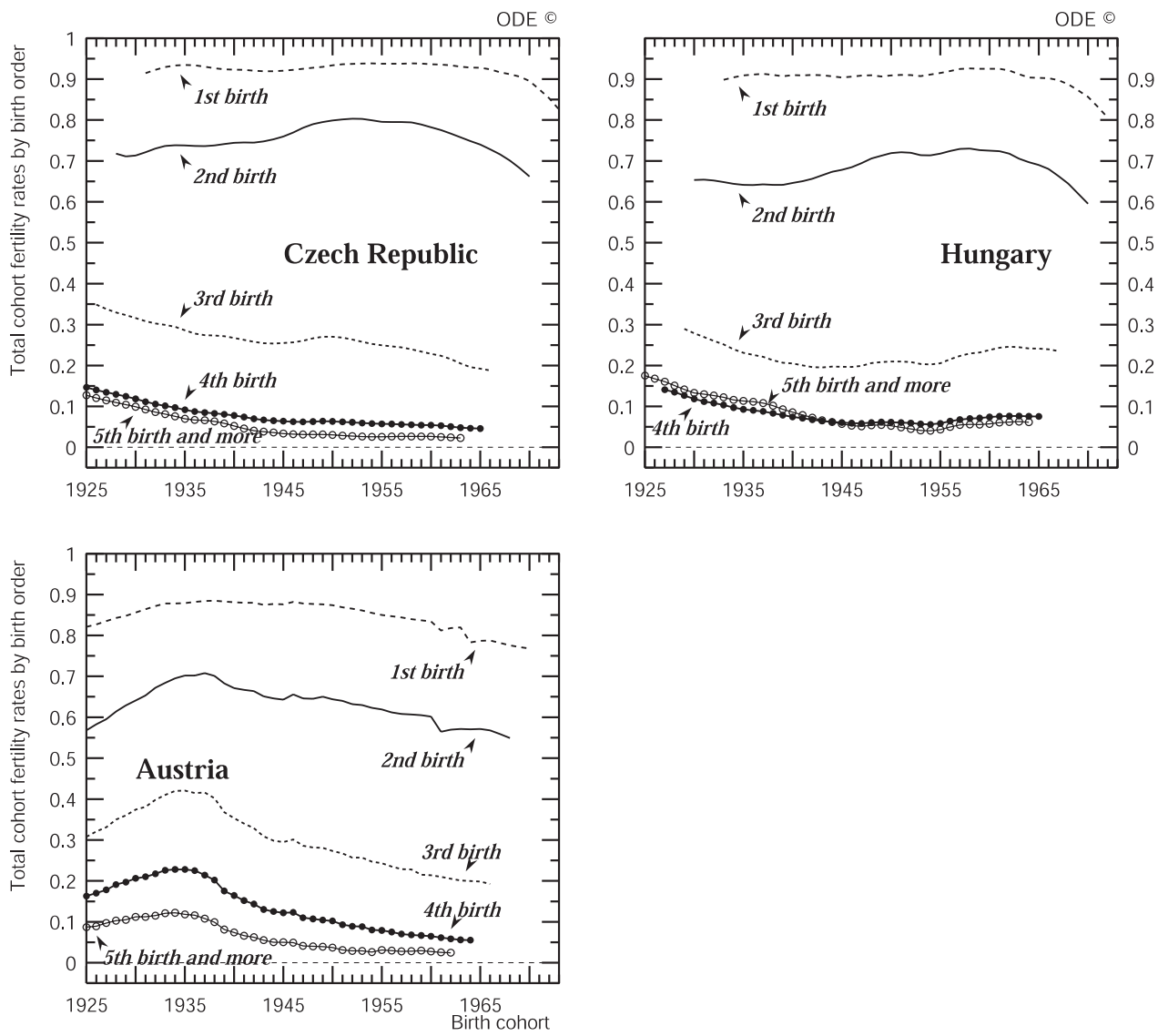

\section{Birth order and childlessness}

A long-term time series of data to explore developments of cohort biological birth order fertility rates in Austria can be obtained by combining estimates based on censuses $^{8}$ with estimates based on vital registration. As these data are not strictly comparable, this leads to a minor discontinuity, discernible especially among first order

8 Estimates of fertility measures based on the 2001 population census were prepared for cohorts born throughout the $20^{\text {th }}$ century by Hanika (2003). 
births and thus also among the data on childlessness. Furthermore, data for international comparative analysis are available only for the Czech Republic and for Hungary ${ }^{9}$.

The highest cohort fertility rates for all birth orders were found among women born in the early 1930s (Figure 8). These rates declined steadily for all subsequent cohorts. The estimated fertility rates for first order births of cohorts born in the late 1960s were coming close to 0.75 births per woman (Figure 8 ). These estimates, if they will hold up in the future, mean that the proportion of women remaining childless is about 25 per cent in the respective cohorts (Figure 9).

The birth order fertility rates for comparable cohorts in the Czech Republic and Hungary were also declining, actually at a faster rate but from a higher base and were therefore not yet as low as in Austria. Likewise the proportions of women remaining childless were increasing rapidly in these countries, but in the cohorts of the late 1960s they were still lower than in Austria by several percentage points (Figure 9).

Available evidence from 23 low-fertility countries indicates that the approximately one quarter of women remaining childless in Austria in the cohorts of the late 1960s is among the highest (Frejka, Sardon 2004). The proportion of women remaining childless in these cohorts was similar in England and Wales. The only country with possibly higher proportions childless was West Germany. According to Birg (2001), 26 per cent of women in the 1960 birth cohort in West Germany remained childless and 32 per cent in the 1965 cohort, respectively. Kreyenfeld (2002) estimates that 24 per cent of German women in the 1960 cohort remained childless at age $35^{10}$. In all three countries the proportions childless were increasing from one generation to the next.

\section{Ideal and expected family size}

In contrast to a number of other countries, perceptions of the ideal family size as well as the expected family size of young women in Austria are quite close to the actual experience as outlined above. The ideal average family size of Austrian women aged 20-34 years old was 1.7 children according to surveys conducted in 2001 (Goldstein et al. 2003). This was identical to Germany, but considerably lower than

9 Birth order data in West Germany and Switzerland were registered within current marriages and therefore cannot be compared with data of the biological birth order per woman without adjustments. Some comparisons with West Germany are made below.

10 The data in Birg (2001) and in Kreyenfeld (2002) for West Germany are not strictly comparable with the data for the other 23 countries due to differences in methods of estimation. Altogether, even though there are some differences among the estimates, they are of the same order of magnitude and point to relatively high rates of childlessness. The reason for the Kreyenfeld estimates being lower is at least in part due to the estimation method used by the author who notes that "we expect that we slightly underestimate the percentage of childless women and overestimate the percentage of higher order births." (p.329) 
in any other country of the European Union. The average for the 15 countries of the EU was 2.1; the ideal family size in France and Finland was 2.5 children. The two-child ideal was quite common (46 per cent) in Austria, but as many as 37 per cent of young women consider one or no child as the ideal. This was twice as many as the average for the EU-15. Only 17 per cent considered a family size of more than 2 children ideal.

The mean expected family size, i. e., the sum of children already born plus those planned for the future, of young Austrian women in 2001 was 1.5 children. This again was well below the EU-15 average of 1.8 children (Goldstein et al. 2003).

\section{Concerns, challenges and potential remedies}

A majority of the Austrian public is concerned with low and declining fertility (Gisser 2003). According to a 2001 survey, 79 per cent of women and men aged 20 to 64 believed that these trends will have a lasting negative impact on societal developments. Throughout Europe the primary concern is focused on population ageing as a consequence of below-replacement fertility, and "there is also a deeply rooted fear of population decline associated with a possible weakening of national identity and loss of international political and economic standing" (Lutz et al. 2003).

In Austria as elsewhere in Europe family-friendly policies were introduced and expanded over the past several decades (United Nations et al., 1999). “...[G]overnments feel an obligation to provide an environment in which it will be easier for women (and men) to balance their family and work-related responsibilities. Childbearing and childrearing are costly and governments believe that society should contribute to cover these costs. Indeed every government provides assistance to parents with a specific blend of benefits, allowances, leaves, tax advantages or in some other form. In some countries, the poorer segments of their populations are receiving contributions following means testing" (UN et al., 1999: 9). Universally European governments proclaim that these policies are not designed to increase fertility. This is apparently confirmed by real developments as "even the most sympathetic assessments found the effect of such policies on fertility at best marginal" (Demeny 2003). The Austrian public has internalised this belief. The general conclusion of the 2001 Austrian population policy survey was that family policies have only a limited effect on the desired number of children (Gisser 2003).

Given the limited effect of "traditional" population-related policies on raising fertility, innovative approaches are being recommended and explored. Almost two decades ago Demeny (1986) suggested possible reforms that "would seek to change institutional arrangements so as to reinforce parental responsibility and authority over children; strengthen the economic security and the status of women within the family; allow parents to benefit directly in old age from having raised children; and make the political system more responsive to the young generation's interests." $\mathrm{He}$ provided several examples of specific policy measures to achieve these ends, such as: 
a. direct allocation of collective educational support to individual parents in the form of vouchers;

b. incorporate the nuclear family; all revenues "should accrue to the corporation, hence be equally vested in the spouses"; this would "provide for greater flexibility of choice between participation in the labour force and specialisation in household production and, in particular, in childrearing;"

c. "link old-age economic security to prior fertility behaviour;"... "[T]his could be best carried out by earmarking an appropriately determined portion of individuals' compulsory social security contributions for transfer to their living but retired parents;"

d. "...let custodial parents exercise children's voting rights until they come of age."

More recently, a group of scientists at the Vienna Institute of Demography have argued that "(P)olicies that aim to affect the timing of births rather than family size may be more acceptable" (Lutz et al. 2003). A cessation in the ongoing trend of delaying births would halt a further increase in the mean age of childbearing. Total period fertility rates would experience an increase and, if stabilised, future population decline with no further delays of births would be smaller than with continued fertility delays.

\section{The foreseeable future}

Despite concern for the societal consequences of low fertility expressed by the Austrian public, the analysis in this paper points in the direction of continued low fertility or even its further decline. A summary of the conclusions emanating from the above diagnosis justifies such an assessment.

Ideal and actual expected family sizes were among the lowest in Europe, 1.7 and 1.5 children per couple, respectively.

The delay in childbearing from one cohort to the next which started with women born in the late 1940s had apparently not yet run its course by the turn of the $21^{\text {st }}$ century; women that were in the midst or at the onset of their childbearing periods, those born during the 1970s, had lower fertility than any previous cohort; whether they were postponing their births and/or many of them deciding not to have any children remains to be seen.

Past experience implies that large proportions of the "delayed" children were never recuperated; among the cohorts that had effectively completed their childbearing, those born during the 1940s, 1950s and early to mid-1960s, at most about half of the delayed children were born when women reached their late twenties or thirties.

In the cohorts of the mid- to late 1960s only about three-quarters of all women had a first birth and around one-quarter of Austrian women remained childless. This was among the highest known proportion of childless women in Europe and probably in the world. 
Childbearing behaviour of its young inhabitants around the turn of the century suggests that Austria will reassume the tradition of having one of the lowest fertility levels in Europe during the initial years, possibly decades, of the $21^{\text {st }}$ century. If these low fertility levels were to persist, a considerable decline in population size as well as rapid population ageing are inevitable, implying the need for radical societal and policy adjustments.

\section{References}

Abramovici, G., 2002, Social Protection in Europe, Statistics in Focus, Theme 3-1/2002, Eurostat.

Birg, H., 2001, Auswirkungen und Kosten der Zuwanderung nach Deutschland, Gutachten im Auftrag des Bayerischen Staatsministeriums des Innern, Bielefeld: Institut für Bevölkerungsforschung und Sozialpolitik

Demeny, P., 1986, Pronatalist policies in low-fertility countries: Patterns, performance, and prospects, Population and Development Review, Supplement to volume 12: 335-358.

—_ 2003, Population policy dilemmas in Europe at the dawn of the twenty-first century, Population and Development Review 29 (1): 1-28.

Frejka, T., 1980, Fertility Trends and Policies: Czechoslovakia in the 1970s, Population and Development Review, 6 (1): 65-93.

Frejka, T. and G. Calot. 2001, Cohort reproductive patterns in low-fertility countries, Population and Development Review 27 (1): 103-132.

Frejka T. and J.-P. Sardon. 2004, Childbearing Trends and Prospects in Low-Fertility Countries: A Cohort Analysis, Dordrecht: Kluwer Academic Publishers.

Gisser, R., 1979, Daten zur Bevölkerungsentwicklung der österreichischen Alpenländer 1819-1913, In: Österreichisches Statistisches Zentralamt, Geschichte und Ergebnisse der zentralen amtlichen Statistik in Österreich 1829-1979. Beiträge zur Österreichischen Statistik, Heft 550: 403-424, und Tabellenanhang (Beiträge Heft 550A): 23-31. Wien: Österreichisches Statistisches Zentralamt.

—_, 2003, Familie, Geschlechterverhältnis, Alter und Migration: Wissen, Einstellungen und Wünsche der Österreicherinnen und Österreicher, Research Report No. 25, Vienna Institute of Demography, Austrian Academy of Sciences.

Goldstein, J., W. Lutz and M. R. Testa. 2003, The Emergence of Sub-Replacement Family Size Ideals in Europe, European Demographic Research Papers, No. 2, Vienna Institute of Demography, Austrian Academy of Sciences, in collaboration with European Observatory on the Social Situation, Demography and Family.

Hanika, A., 2003, Volkszählung 2001: Paritäts-Fertilitätstafeln, Statistische Nachrichten, vol. 58: 90-96, Statistik Austria.

Hobcraft, J. and K. Kiernan, 1995, Becoming a Parent in Europe, Evolution or Revolution in European Population, Proceedings of the European Population Conference, Milano. 
Kirk, D., 1946, Europe's Population in the Interwar Years, Princeton, NJ: League of Nations and Princeton University Press.

Kreyenfeld, M., 2002, Parity-specific birth rates for West Germany: An attempt to combine survey data and vital statistics, Zeitschrift für Bevölkerungwissenschaft 27 (3): 327-357.

Lutz, W., B. C. O'Neill, S. Scherbov, 2003, Europe's population at a turning point, Science, 299: 1991-1992.

Prinz, C., W. Lutz, V. Nowak and C. Pfeifer, 1998, Standard Country Report: Austria, Fertility and Family Surveys in Countries of the ECE Region, Economic Studies 10h, United Nations: New York and Geneva.

Statistik Austria, 2001, Demographisches Jahrbuch 2000, Wien

United Nations Economic Commission for Europe, Council of Europe and United Nations Population Fund, 1994, Country Statement: Austria, Proceedings of European Population Conference, 23-26 March 1993, vol. 2, United Nations: New York and Geneva.

United Nations Economic Commission for Europe, United Nations Population Fund, Council of Europe and Hungarian Central Statistical Office, 1999, Population in Europe and North America on the Eve of the Millennium: Dynamics and Policy Responses, Regional Population Meeting, 7-9 December 1998, Budapest, Hungary, United Nations: New York and Geneva.

World Bank, 2002, GNI per capita, Atlas Method and PPP, Data and Statistics, Data by Topic, Gross National Product (www.worldbank.com) 